\title{
Material Culture in Central Asia and the Middle East II
}

\author{
24-25 Dhü al Qadah 1414/5-6 May 1994 \\ School of Oriental and African Studies \\ University of London, London, United Kingdom
}

A two-day conference on material culture in the Islamic Middle East and Central Asia with special refenence to the innovation and diffusion of tochnology in the areas of engineering, architecture, cappet manufacture, and medicine, among others, was held in London between 5-6 May 1994. It was hosted by the School of Oriental and African Studies (SOAS), University of London, United Kingdom. As conveners of the conference, Keith McLachlan (SOAS, University of London, UK) and Richard Tapper (SOAS, University of London, UK) pointed out that it was the latest in a series of conferences to be held at SOAS on various aspects of material culture. Earlier ones were entitled "Culinary Cultures of the Middle East" (April 1992)," The Language of Dress in the Middle East" (November 1992), and the first conference on "Material Culture in Central Asia and the Middle Bast" (June 1993).

Participants reviewed nomadic, pastoralist, cultivator, and urban systems and assessed the regions' role as centers for innovation and the diffusion of tectunologies, principally during the Islamic period. The first session of the conference's keynote speech was chaired by Ghazi Algosaibi (Saudi Arabian ambassador to the United Kingdom) and included a revealing paper titled "Arab and Islamic Contributions to European Civilization." Rifat Ebied (professor of Semitic Studies, University of Sydney, Australia, and currently Visiting Fellow, Trinity Hall, Cambridge, UK) elaboratod upon the historical issues conceming the production of knowledge in the Muslim world and its transmission to Europe via educational establishments. Ebied pointed out that the Arabs inherited the scientific tradition of late antiquity, preserved and expanded it with valuable additions, and finally passed it on to Europe. He outlined the major segments of the Muslim world's massive contribution to westem civilization, focusing on the influence of the Islamic legacy on Europe in the various fields of knowledge, with particular emphasis on the Islamic origins of the system of higher education (i.e., the creation of the university as an institution). In the second session, Donald Hill read a paper entitled "Science and Technology in Islamic Building Canstruction," in which he examined some of the scientific and technological content of 
construction projects in the medieval Islamic world. In his introduction, he listed the various trades and professions employed on building sites as largely derived from the accounts of building of the Round City of Baghdad. He also touched upon various techniques used in building construction, including methods of surveying and the application of empirical hydraulic engineering to the construction of dams. In the final part of his paper, Hill discussed the likelihood of the transmission of the pointed arch, a key element in European Gothic architecture, from the Islamic world to the West.

Michael Rogers' (SOAS, University of London, UK) "The Madrassahs of the Near East and Their Curriculum," which was read at the third session, dealt with the institutions of higher learning in the Muslim world. He reviewed the establishment of madrassahs, their educational policy, and the contents of the classes in the Islamic Near East. He explained how knowledge is produced and transmitted within the madrassahs as well as their contribution to Muslim civilization. Susan Roaf (Oxford Brookes University, Oxford, UK) spoke on "Sustainable Buildings: Middle Eastem Traditional Systems for the Future," which foeused on Central Asia and the Middle East. These areas, he claimed, have one of the richest building types in the world, due to a wide range of geographical, social, material, technological, climatic, religious, and other constraints as well as temporal influences. In addition, they are characterized by design features that give them unique regional identities. She argued that while many people see these building types in the context of museum pieces, they have an important role to play in the development of the future buildings. According to Roaf, "for global, economic, and political reasons, we will need, in the next century, to build more culturally and climatically more appropriate buildings than those modern buildings that are fashionable throughout the region today that are so destructive of the environment."

The first day of the conference ended with the reading of two additional papers: a) "Wind and Water Mills in Iran and Afghanistan" was presented by Michael Harverson (British Institute of Persian Studies, London, UK) and covered the historical development of technologies in the construction of wind and water mills, their economic utility in industrial applications, and their fate in the modern world; and b) "Icehouses and Pigeon Towers on the Iranian Plateau" was presented by Elisabeth Beazley (British Institute of Persian Studies, London, UK), in which she conceded that "the ice-houses and pigeon-towers of the plateau are among the most astonishing buildings to be found anywhere."

The second day began with "From the Rashidiyya to the Orion," in which Peter Andrews (University of Koln, Germany) covered Mongol- 
Turkic tents. This was followed by a paper on "Material Culture of Pastoral Nomads: Reflections based on Arab and Afghan Materials," presented by Klaus Fendinand (Dansk Nomadeforskning, Denmark), who drew on his previous work, Bedouins in Qatar (1993), a great deal. Jon Thompson's speech focused on "Looms, Carpets, and Kelims in the Islamic World," while Richard Tapper (SOAS, University of London, UK) dwelt on "Felt Making in Iran, Afghanistan, and Turkey." Two papers were devoted to medical issues: a) Derek Lithium (Professor Emeritus in Arabic and Islamic Studies, Edinburgh University and Honorary Research Fellow, University of Manchester, UK) presented an informative paper on the treatment of tuberculosis of the lungs. His paper, "TB and Its Treatment in Medieval Islam," gave a very good account of Ișbāq ibn Sulaymān's (ca. 855-950 CE) approach to hectice fever and its treatment; and b) "Al Tibb al Nabawi: The Prophet's Medicine," was read by Ghada Karmi (SOAS, University of London, UK). The last paper, delivered by Mahmoud Abdullah Zadeh (director, Research Information Department, and editor, Tahqiqat-i Islami) explored "The Political Significance of the Bazgar in Iran."

Talip Küçükcan Research Fellow, Türkjye Diyanet Vakfi Centre for Islamic Studies Istanbul, Turkey 